\title{
Erratum to: The Arizona home language survey: The under-identification of students for English language services
}

\author{
Claude Goldenberg • Sara Rutherford-Quach
}

Published online: 10 March 2012

(C) Springer Science+Business Media B.V. 2012

\section{Erratum to: Lang Policy \\ DOI 10.1007/s10993-011-9224-5}

The original version of the article has been published with certain errors that are corrected below:

The sentence below the heading Procedures should read as:

District A is one of the largest school districts in Arizona, although still considered a "medium-sized" district by national standards.

The third line in heading Study 1 should read as:

If students' parents indicated a language other than English in response to any of the three ... (They didn't make "students" possessive here)...

The first paragraph in the Conclusion should read as:

Results of both studies are very clear. The one-question PHLOTE led to an under-identification of ELLs. As a result, students likely to need English learner support services will not receive them.

The online version of the original article can be found under doi:10.1007/s10993-011-9224-5.

C. Goldenberg $(\bowtie) \cdot$ S. Rutherford-Quach $(\bowtie)$

Stanford University, Stanford, CA, USA

e-mail: cgoldenberg@stanford.edu

S. Rutherford-Quach

e-mail: ruthersa@stanford.edu 